\section{Mucocele and Fibroma: Treatment and Clinical Features for Differential Diagnosis}

Rodrigo Alexandre Valério', Alexandra Mussolino de Queiroz'1, Priscila Coutinho Romualdo', Luiz Guilherme Brentegani², Francisco Wanderley Garcia de Paula-Silva ${ }^{1}$
'Department of Pediatric Dentistry, Ribeirão Preto School of Dentistry, University of São Paulo, Ribeirão Preto, SP, Brazil ${ }^{2}$ Department of Morphology, Stomatology and Physiology, Ribeirão Preto School of Dentistry, University of São Paulo, Ribeirão Preto, SP, Brazil

Correspondence: Francisco Wanderley Garcia de Paula-Silva, Avenida do Café S/N, 14040-904 Ribeirão Preto, SP, Brasil. Tel: 55-16-3602-4143 e-mail: franciscogarcia@forp.usp.br

\begin{abstract}
Mucocele is a benign lesion occurring in the buccal mucosa as a result of the rupture of a salivary gland duct and consequent outpouring of mucin into soft tissue. It is usually caused by a local trauma, although in many cases the etiology is uncertain. Mucocele is more commonly found in children and young adults, and the most frequent site is the lower inner portion of the lips. Fibroma, on the other hand, is a benign tumor of fibrous connective tissue that can be considered a reactionary connective tissue hyperplasia in response to trauma and irritation. They usually present hard consistency, are nodular and asymptomatic, with a similar color to the mucosa, sessile base, smooth surface, located in the buccal mucosa along the line of occlusion, tongue and lip mucosa. Conventional treatment for both lesions is conservative surgical excision. Recurrence rate is low for fibroma and high for oral mucoceles. This report presents a series of cases of mucocele and fibroma treated by surgical excision or enucleation and the respective follow-up routine in the dental clinic and discusses the features to be considered in order to distinguish these lesions from each other.
\end{abstract}

Key Words: mucocele, fibroma, enucleation, differential diagnosis, histology.

\section{Introduction}

Mucocele is a benign cystic lesion, asymptomatic, usually containing saliva in its interior, and caused by disruption of the ducts of minor salivary glands or the presence of calculus (sialolith) inside gland ducts. The etiology is related to local trauma (1). Bullous appearance of mucous cyst occurs either by the outpouring of mucus into the connective tissue or by preventing drainage through damaged excretory duct (2).

The lesions are more common in the inner portion of the lower lip, although they can also be found in the buccal mucosa, in the tongue and on the floor of the mouth $(2,3)$. Mucoceles are usually rounded, slightly bluish or translucent, present slow growth (4), and are more common among children and young adults. The size of oral mucoceles varies from $1 \mathrm{~mm}$ to several centimeters in diameter and their duration may range from days to years. For clinical differential diagnosis, fibrous hyperplasia, focal papilloma, lypoma or fibroma should be considered (2).

Some oral mucoceles involute and disappear spontaneously after a short time, while others are chronic and require surgical removal or marsupialization. Microscopically, mucoceles present a granulomatous tissue involving a mucosal liquid content, usually mucin. If concomitant inflammation occurs, neutrophils and macrophages can be found (2).

Benign and malignant neoplasm of varied origins can develop in oral structures. The autonomy of neoplasm is characterized by absence of response to control mechanisms and no dependence on continuity of a stimulus. Proliferative processes that occur in the oral cavity are an interesting and controversial field of study because their nature may be either reactionary or neoplastic (5).

Fibromas are asymptomatic lesions found more frequently in the buccal mucosa, in the fourth decade of life. They present a smooth surface, nodular appearance, hard consistency and a sessile base. Color is similar to the mucosa or may be bluish, measuring up to $2 \mathrm{~cm}$ in diameter, and displaying slow growth due to low mitotic index. Lesions are often encapsulated, usually well delimited and do not produce metastasis. Microscopically, fibromas appear as a nodular mass of fibrous connective tissue with collagen fibers mixed to fibroblasts and covered by a keratinized squamous epithelium $(5,6)$.

Several therapeutic procedures have been described in the literature for both mucoceles and fibromas, such as surgical excision with scalpel, ablation with carbon dioxide $\left(\mathrm{CO}_{2}\right)$ and erbium-doped yttrium aluminium garnet (Er:YAG) lasers, marsupialization, and cryosurgery. Oral mucoceles can alternatively be treated by the technique of filling the interior of the lesion by dental alginate followed by enucleation and micromarsupialization $(7,9)$. If recurrence occurs, it is necessary to remove the adjacent salivary gland. Surgical enucleation is the most widely used form 
Table 1. Demographic information of the patients, clinical features of the lesions, and clinical and histological diagnosis

\begin{tabular}{|c|c|c|c|c|c|c|c|c|}
\hline \multirow{2}{*}{ Case } & \multirow{2}{*}{$\begin{array}{l}\text { Age } \\
\text { (years) }\end{array}$} & \multicolumn{2}{|c|}{ Lesion } & \multirow{2}{*}{$\begin{array}{l}\text { Clinical } \\
\text { features }\end{array}$} & \multirow{2}{*}{ Pain } & \multirow{2}{*}{$\begin{array}{l}\text { Detection } \\
\text { time }\end{array}$} & \multirow{2}{*}{$\begin{array}{l}\text { Clinical } \\
\text { diagnosis }\end{array}$} & \multirow{2}{*}{$\begin{array}{c}\text { Histological } \\
\text { diagnosis }\end{array}$} \\
\hline & & Size $\left(\mathrm{cm}^{2}\right)$ & Volume $\left(\mathrm{cm}^{3}\right)$ & & & & & \\
\hline A & 6 & 0.49 & 0.34 & $\begin{array}{l}\text { Bullous, soft, smooth } \\
\text { surface, pediculated base }\end{array}$ & Absent & 4 years & Mucocele & $\begin{array}{l}\text { Mucous extravasation } \\
\text { phenomena (mucocele) }\end{array}$ \\
\hline B & 11 & 0.35 & 0.175 & $\begin{array}{l}\text { Bullous, soft, smooth } \\
\text { surface, sessile base }\end{array}$ & Absent & 3 months & Mucocele & $\begin{array}{l}\text { Mucous extravasation } \\
\text { phenomena (mucocele) }\end{array}$ \\
\hline C & 8 & 0.49 & 0.34 & $\begin{array}{l}\text { Bullous, soft, smooth } \\
\text { surface, sessile base }\end{array}$ & Absent & 2 years & Mucocele & $\begin{array}{l}\text { Mucous extravasation } \\
\text { phenomena (mucocele) }\end{array}$ \\
\hline D & 37 & 0.16 & 0.064 & $\begin{array}{l}\text { Nodular, hard, smooth } \\
\text { surface, sessile base }\end{array}$ & Absent & 1 year & Fibroma & Fibroma \\
\hline E & 8 & 0.25 & 0.125 & $\begin{array}{l}\text { Nodular, hard, smooth } \\
\text { surface, pediculated base }\end{array}$ & Absent & 1 year & Fibroma & Fibroma \\
\hline $\mathrm{F}$ & 3 & 0.61 & 0.51 & $\begin{array}{l}\text { Nodular, hard, irregular } \\
\text { surface, sessile base }\end{array}$ & Absent & 2 months & Fibroma & Fibroma \\
\hline
\end{tabular}
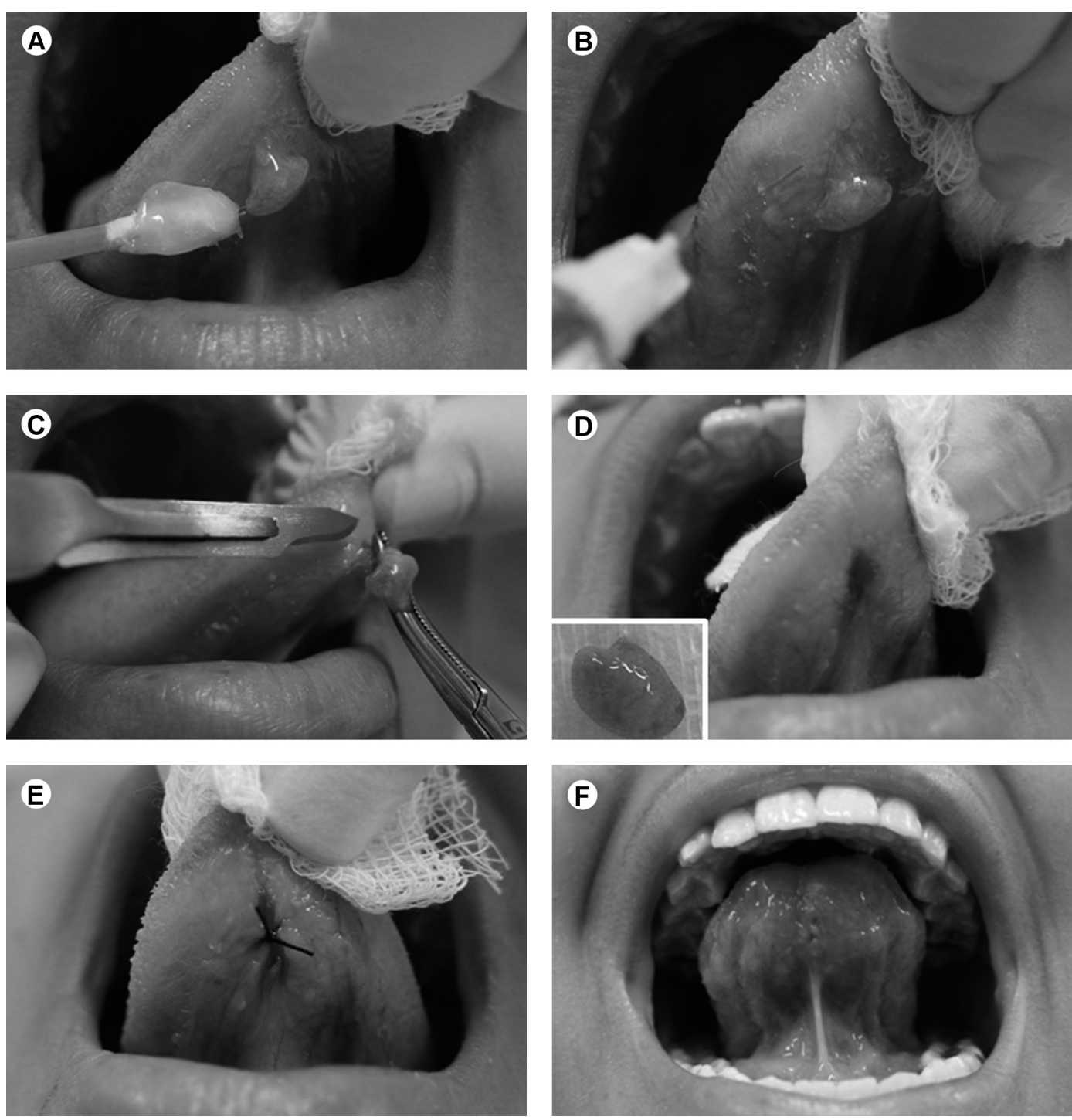

Figure 1. Surgical enucleation of a Blandin-Nuhn mucocele. A: Application of a topical anesthetic paste. B: Infiltrative local anesthesia in equidistant points around the lesion. C: Incision of the base of the lesion with a scalpel blade. D: Exposed connective tissue and mucocele removed (insert). E: Suture with a silk thread. F: Seventh-day clinical follow-up. 
of treatment and consists in complete removal of the lesion during the surgical procedure (3).

This report presents a series of cases of mucocele and fibroma treated by surgical excision or enucleation and the respective follow-up routine in the dental clinic and discusses the features to be considered in order to distinguish these lesions from each other.

\section{Case Report}

Cases of five males and one female who sought dental treatment at our Dental School are presented. Information was collected under Institutional Review Board approval (2010.1.1479.58.1). During review of clinical history, the patients/guardians informed presence of asymptomatic round lesions in the mouth and absence of systemic diseases. Extraoral physical examination revealed no alteration.
Intraoral clinical examination revealed well circumscribed bullous/nodular lesions located in lip mucosa, tongue or gingival tissues (Table 1).

The technique of surgical removal of the lesions was chosen among the possible therapeutic options, and surgeries were performed at the outpatient facilities with no need of hospitalization (Figs. $1 \mathrm{~A}-\mathrm{F}$ and $2 \mathrm{~A}-\mathrm{F}$ ). After 1-min preoperative mouthwash with an antiseptic solution of $0.12 \%$ chlorhexidine digluconate (Periogard ${ }^{\oplus}$; Colgate Palmolive, São Paulo, SP, Brazil), a topical anesthetic (Benzotop; DFL, Rio de Janeiro RJ, Brazil) was applied around the lesions for 3 min followed by an infiltrative local anesthesia (3\% mepivacaine/1:100,000 noradrenaline (Mepiadre 100; DFL) at 4 equidistant points around the lesions, using short needles (Unoject; DFL) mounted in an aspirating Carpule syringe. The base of the lesions was
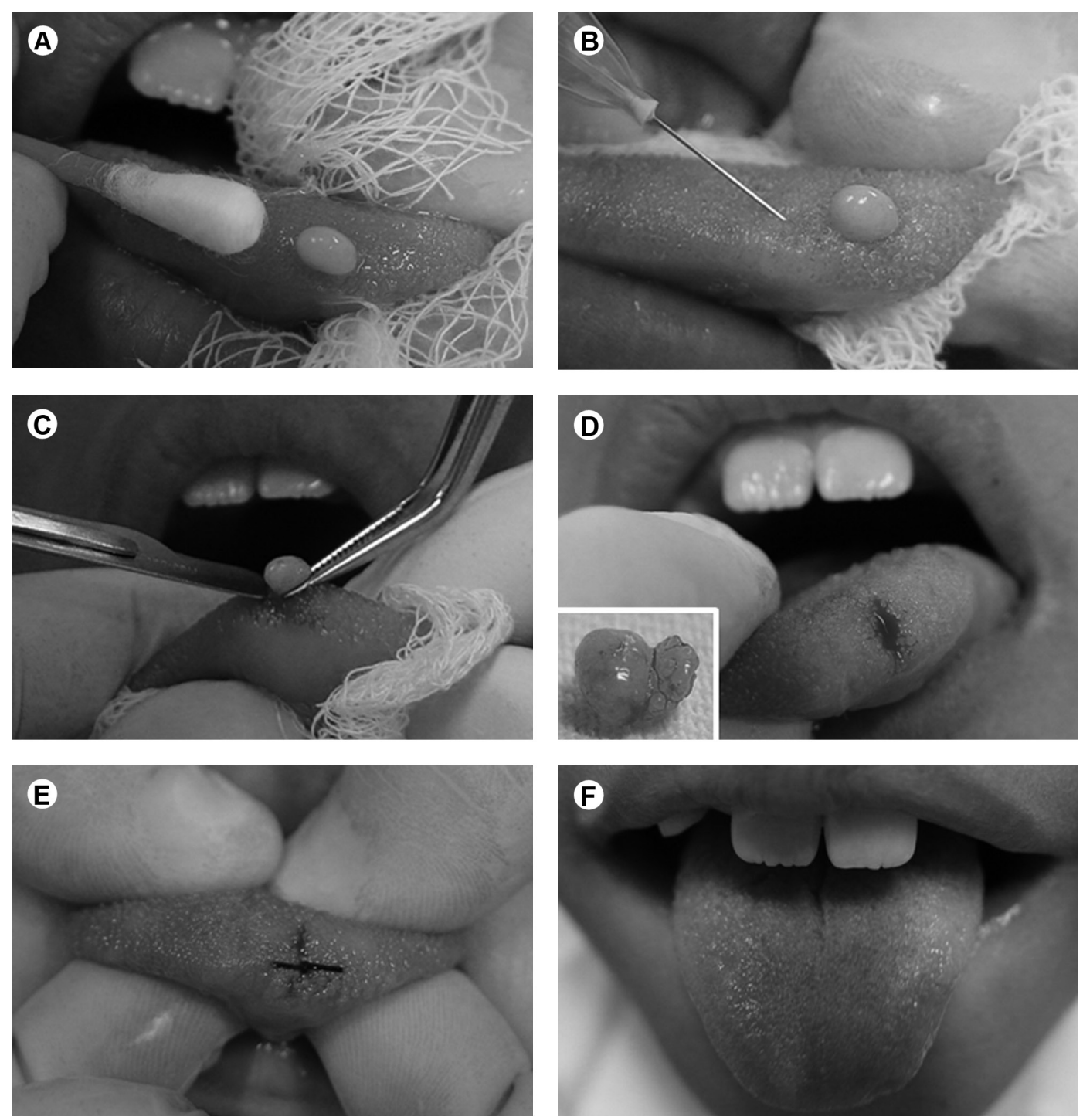

Figure 2. Surgical enucleation of a fibroma. A: Application of a topical anesthetic paste. B: Infiltrative local anesthesia in equidistant points around the lesion. C: Incision of the base of the lesion with a scalpel blade. D: Exposed connective tissue and fibroma removed (insert). E: Suture with a silk thread. F: Seventh-day clinical follow-up. 
clamped with Halstead tweezers, incised with a scalpel blade \#15, and the lesions were removed and sent to histopathological analysis. The soft tissues were sutured with a silk thread (Ethicon 3-0; Johnson \& Johnson, São Paulo, SP, Brazil). Postoperative care recommendation and prescription of pain relievers were done and the patients returned to the dental clinic 7 days later for removal of sutures and clinical follow-up of the healing process.

The histopathological analysis confirmed the clinical diagnosis. The mucoceles presented as cavity partially filled or not by an amorphous material similar to mucus, surrounded by a fibrous connective tissue, infiltrated by chronic inflammatory cells, and covered with a stratified squamous epithelium. In some cases, fragments of mucous gland with dilated ducts were seen. Fibromas presented as a fibrous connective tissue containing fibroblasts with a few chronic inflammatory cells, surrounded by an atrophic parakeratinized squamous epithelium.

\section{Discussion}

Mucoceles and fibromas, depending on their clinical features, can be misdiagnosed as other pathologies present in the oral cavity. It is therefore important to accomplish eferion $(2,11)$. In the series of cases reported in this study, histopathologic analysis confirmed the clinical diagnosis.

Regarding the etiology and pathogenesis of the mucocele, mucus retention cysts result from obstruction of salivary duct by a sialolith or a scar in the ductus; mucin is therefore surrounded by the ductal epithelium. While mucus retention cysts are associated with a traumatic injury of the ductus, mucous extravasation phenomenon results from extravasation of saliva to the adjacent connective tissue spaces $(9,10)$. In the clinical cases reported here, the histopathologic assessment indicated a mucus extravasation phenomenon to adjacent tissues, since the presence of a ductal epithelium was not observed, but a connective tissue infiltrated by mucus surrounded by some chronic inflammatory cells covered by a parakeratinized stratified squamous epithelium. All three cases of mucocele presented a history of associated trauma, soft consistency on palpation and a clinically detected smooth surface.

Usually mucocele of minor salivary glands are located on the lower lip mucosa (Cases A and C) $(8,11)$, buccal mucosa, soft palate, and the retromolar trigone region $(4,10)$, without predilection by gender $(4,12,13)$. BlandinNuhn mucoceles (Case B) in the ventral portion of the tongue are less frequent $(3,18)$.
Fibroma, on the other hand, is a lesion of connective tissue nature, characterized by proliferation of fibroblasts and deposition of collagen fibers in short and cluttered beams, considered by some authors as a true neoplasm $(10,14)$. The cases shown here presented either smooth or irregular surface, sessile or pedunculated base, but all presented hard consistency to palpation, suggesting clinical diagnosis of fibroma. Histology confirmed clinical diagnosis.

Several options for treatment of intraoral lesions are available, including marsupialization, $\mathrm{CO}_{2}$ and $\mathrm{Er}, \mathrm{Cr}: \mathrm{YSGG}$ laser ablation $(15,16)$, cryotherapy and surgical enucleation (17). The latter is the most widely used technique for definitive removal of the lesion, with a wide safety margin to prevent recurrence (3). This treatment is simple and inexpensive and can be performed under local anesthesia. In Pediatric Dentistry, the procedure can be done using behavior management techniques, which are relatively well tolerated by children.

In conclusion, mucocele can be frequently found in the lower lips of young patients and is associated with some kind of local trauma. Fibroma is found more often in adult patients in the buccal mucosa, resulting from constant irritation of the soft tissue. Both lesions can be treated by excisional biopsy using the surgical enucleation technique, which presents advantages such as removal of the entire lesion to provide biological material for histopathologic examination.

\section{Resumo}

Mucocele é uma lesão comum na mucosa bucal, que resulta da ruptura de um ducto de glândula salivar e consequente derramamento de mucina para o interior dos tecidos moles circunjacentes. Frequentemente este derrame resulta de trauma local, embora em muitos casos a etiologia seja indefinida. É uma lesão não infecciosa benigna, que frequentemente afeta a cavidade bucal de crianças e adultos jovens, localizando-se geralmente na porção interna dos lábios inferiores. Por outro lado, o fibroma é um tipo de tumor benigno do tecido conjuntivo fibroso que pode ser considerado uma hiperplasia reacional do tecido conjuntivo em resposta a traumas e irritação. Geralmente são nodulares, com consistência firme, assintomáticos, coloração semelhante à da mucosa, base séssil, superfície lisa, localizados na mucosa jugal ao longo da linha de oclusão, lingua e mucosa labial. 0 tratamento convencional para ambas as lesões é a excisão cirúrgica conservadora, sendo que sua recorrência é rara para fibromas e alta para as mucoceles. Este trabalho relata casos clínicos de mucocele e fibroma, tratados pela técnica de excisão cirúrgica ou enucleação, bem como descreve a proservação no consultório odontológico. As características importantes para o diagnóstico diferencial dessas lesões são discutidas.

\section{References}

1. Porter SR, Scully C, Kainth B, Ward-Booth P. Multiple salivary mucoceles in a young boy. Int J Paediatr Dent 1998;8:149-151.

2. Laskaris $\mathrm{G}$. Color atlas of oral diseases in children and adolescents. New York: Thieme Medical Publishers Inc., 2000.

3. Adachi P, Pires-Soubhia AM, Horikawa FK, Shinohara EH. Mucocele of the glands of Blandin-Nuhn. Clinical, pathological, and therapeutical aspects. Oral Maxillofac Surg 2011;15:11-13.

4. Bermejo A, Aguirre JM, Lopez P, Saez M. Superficial Mucocele. Oral Surg 
Oral Med Oral Pathol Oral Radiol Endod 1999;88:469-472.

5. Bahadure RN, Fulzele P, Thosar N, Badole G, Baliga S. Conventional surgical treatment of oral mucocele: a series of 23 cases. Eur J Paediatr Dent 2012;13:143-146.

6. Neville BW, Damm DD, Allen CM, Bouquot JE. Oral \& Maxillofacial Pathology. St. Louis: Saunders, 2009.

7. Sagari SK, Vamsi KC, Shah D, Singh V, Patil GB, Saawarn S. Micromarsupialization: a minimally invasive technique for mucocele in children and adolescents. J Indian Soc Pedod Prev Dent 2012;30:188191.

8. Sugerman PB, Savage NW, Young WG. Mucocele of the anterior lingual salivary glands (glands of Blandin and Nuhn): report of 5 cases. Oral Surg Oral Med Oral Pathol Oral Radiol Endod 2000;90:478-482.

9. Baurmash HD. Mucoceles and ranulas. J Oral Maxillofac Surg 2003;61:369-378.

10. Regezi JA, Sciubba JJ, Richard K. Oral Pathology: Clinical Pathologic Correlations. 5th ed. Philadelphia: Saunders Elsevier; 2008.

11. Mandel L. Multiple superficial oral mucoceles: case report. J Oral Maxillofac Surg 2001;59:928-930.

12. Harrison JD. Salivary mucoceles. Oral Surg Oral Med Oral Pathol
1975;39:268-278.

13. Bodner $\mathrm{L}, \mathrm{Tal} H$. Salivary gland cysts of the oral cavity: clinical observation and surgical management. Compendium 1991;12:154156.

14. Esmeili T, Lozada-Nur F, Epstein J. Common benign oral soft tissue masses. Dent Clin North Am 2005;49:23-40.

15. Niccoli-Filho $W$, Morossoli AR. Surgical treatment of ranula with carbon dioxide laser radiation. Lasers Med Sci 2004;19:12-14.

16. Zola M, Rosenberg D, Anakwa K. Treatment of a ranula using an ErCr:YSGG laser. J Oral Maxillofac Surg 2006;64:823-827.

17. Bahadure RN, Fulzele $P$, Thosar N, Badole G, Baliga S. Conventional surgical treatment of oral mucocele: a series of 23 cases. Eur J Paediatr Dent 2012;13:143-146.

18. Santos TS, Filho PR, Piva MR, Khalil-Karam F. Mucocele of the glands of Blandin-Nuhn after lingual frenectomy. J Craniofac Surg 2012;23:657658.

Received August 11, 2012 Accepted August 18, 2013 